\title{
Comparison of the effect of hatchery disinfection with peracetic acid andglutaraldehydeassociated with quaternary ammonia compounds on the tracheal mucosa of one day old chicks
}

\author{
Patrícia Alves Teixeira ${ }^{1^{*}}$, Erica Crosara Ladir de Lucca ${ }^{2}$, \\ Adriana Tereza Machado Moura Petrocelli ${ }^{1}$, Paula Fernanda Sousa Braga ${ }^{1}$, \\ Marcelo Emilio Beletti ${ }^{1}$
}

\begin{abstract}
This study aimed at identifying lesions in the respiratory tract of chickens caused by hatchery disinfection, performed by micro-sprinkler with peracetic acid and ammonia associated with glutaraldehyde. The experiment was conducted at a hatchery in Uberlândia - MG, in June 2013. Three hatcheries were employed, each one using a different treatment process. All process had been conducted in the same room and had the same mechanisms of temperature, humidity and ventilation control. Process 1 (P1) was sprayed with a solution of peracetic acid (two $\mathrm{ml}$ per liter of water, total of $300 \mathrm{ppm}$ ); P2 was sprayed with a solution of glutaraldehyde associated with ammonia (one $\mathrm{ml}$ of water per liter, total of 450 and 75 ppm); and P3 was sprayed only with distilled water. At the end of 48 hours, 16 chicks per treatment process were collected at each outbreak to remove the trachea. Each trachea was divided into two samples. One sample was processed for evaluation by optical microscope and another was processed for evaluation by transmission electron microscope. The observation of the slides had 10 fields for evaluation, so that all tracheal mucosa on each slide was observed for the definition of scores according to the degree of the found lesions. At the result, there was a significant difference only in the material evaluated by light microscopy between chicks exposed to environmental ammonia and glutaraldehyde (P2) related to the control group (P3), considering that these chicks showed more severe injuries, such as areas with less cilia and areas of tracheal mucosa flaking. Chicks exposed to disinfection with peracetic acid in hatcheries did not show lesions of the tracheal mucosa. Therefore, when using the dosages in this study, peracetic acid can be used for the disinfection of hatcheries to reduce the contamination present during the process, while causing less damage to the tracheal mucosa of chicks.
\end{abstract}

Keywords: disinfectants, trachea, cilia, hatchers, Gallus gallus.

\footnotetext{
${ }^{1}$ Programa de Pós Graduação em Ciências Veterinárias da Universidade Federal de Uberlândia.

${ }^{2}$ Instituto Federal do Triângulo Mineiro, Uberaba, Brasil.

* Corresponding author: patyvetufu@gmail.com
} 


\section{Introduction}

The incubator is a strategic environment for poultry production, which has strong links to poultry farms. As such, it has impacts on the performance and growth of broiler chickens (GONZALES and CAFÉ, 2003).

The main goal of the incubator is to transform eggs into chicks, with the desired volume, deadline and quality. It happens while reducing the incidence of abnormalities and contamination. At the same time, the incubator attends to the needs and expectations of poultry production, at the lowest possible cost. The concern of the poultry industry for maintaining high productivity rates brought about the introduction of measures that prevent the introduction and infestation of pathological agents into the incubator (HAYRETDAG and KOLANKAYA, 2008).

Among the biosecurity procedures used in broiler chicken hatcheries, the disinfecting of incubators and hatchers is a routine practice. The cleaning and disinfecting of machines is vital for protecting eggs and chicks against disease, as well as reducing the number of pathogens in the incubation environment. After oviposition, it could possibly have eggshell contamination by microorganisms present in the environment. The bacteria is able to penetrate the shell and infect the embryo, resulting in the embryo death and in low quality chicks (HAYRETDAG and KOLANKAYA, 2008).

Formaldehyde has been established as the disinfectant of choice among those disinfectants used during the incubation and hatching egg process. This is due mainly to its ease in administration and efficiency against a wide spectrum of microorganisms. The disinfecting is performed with the aim of reducing pressure from contamination inside the incubation and hatching machines (FREITAS et al., 2006). However, studies show that formaldehyde causes lesions through the flaking of the tracheal cilia membrane of chicks submitted to disinfection by fungicide in hatcheries (FREITAS et al., 2006). In addition, the industry is currently searching for 
other disinfectants as substitutes to formaldehyde due to restrictions in its use applied by ANVISA (Agência Nacional de Vigilância Sanitária), resolution RDC $n^{0} 91 / 2008$ (BRASIL, 2008). The peracetic acid solutions and/or glutaraldehyde solution associated with quaternary ammonia are most commonly the disinfectants used for substituting formaldehyde. The goal for the present study is to identify possible tracheal lesions in chicks, caused by hatchery disinfectants, when using micro-spraying with peracetic acid and glutaraldehyde associated with quaternary ammonium compounds.

\section{Material and methods}

The experiment was performed at a hatchery in the municipal of Uberlândia - MG, in July of 2013 and was approved by the ethics committee for the use of animals at the Federal University of Uberlândia (UFU), under the protocol number of 062/13. Each treatment process used 16 chicks, a total of 48 chicks from the Cobb lineage, supplied by breeders, from the same batch at 35 weeks old, free from Mycoplasma gallisepticum, Mycoplasma synoviae, as well as free from bacteria of the Salmonella sp genre.

The eggs were incubated in machines from Petersime, model VB504 of multiple stage with a capacity for holding 50400 eggs, following a normal incubation routine in a commercial hatchery. The incubators used in this research study were incubating eggs at full capacity, with the eggs and research trays correctly identified to avoid misidentification. Before incubation all the eggs were submitted to the same procedures, from the poultry farm to the hatchery. At the poultry farm all the eggs were disinfected by immersion in peracetic acid solution, diluted at $2 \mathrm{ml} / \mathrm{liter}$ immediately after collection of the eggs from the aviary. The disinfection process of eggs after collection is a routine biosecurity procedure of broiler farms. 
The full incubation time was 504 hours over the full treatment, in which the concluding 48 hours had been in the hatcheries. Those were also manufactured by Petersime, model KK168, with capacity to hold 16800 eggs, where the eggs and chicks were exposed to the treatment procedure presented in this study. The hatcheries used in the study were also at their full capacity. The eggs and trays used in the study were correctly identified to avoid errors.

Three treatment procedures were performed, one procedure per hatchery, taking into consideration that all the hatcheries were in the same room with the same temperature, humidity and ventilation control mechanisms. The disinfection system was automatic with a jet of $45 \mathrm{ml}$ of disinfectant being sprayed into each hatchery at every 30 minutes. The total period of time in the hatchery was 48 hours, and the spraying was performed automatically over the full period. The birth window was of approximately 26 hours, that is, the spraying started at the egg stage in the hatchery and at the time of hatching the hatchlings were exposed to the disinfectant spray, with an exposure period of 48 hours, for all procedures. These procedures were:

P1-spraying the hatchery with peracetic acid solution at $15 \%$. Diluted at two $\mathrm{ml}$ per liter of water (300 ppm),

P2 - spraying the hatchery with glutaraldehyde solution associated with quaternary ammonia (benzalkonium chloride). Glutaraldehyde at $42.5 \%$ (425 ppm) and benzalkonium chloride at $7.5 \%$ (75 ppm). Diluted at one $\mathrm{ml}$ per liter of water, and P3 - control - spraying distilled water.

After the completing 48 hours of disinfection of the hatcheries, 16 chicks from each procedure were removed for evaluation (maintaining a height of $1.20 \mathrm{~m}$ in relation to the floor). The chicks have been placed in the trays closest to the spray nozzle of each machine; thus, having the 
maximum exposure to the products. The position of the hatching trays was the same for all procedures, that is, in the different hatcheries, avoiding in this fashion differences in exposure of the chicks to the disinfectant products. The chicks were anesthetized using ketamine hydrochloride, at a dose of $60 \mathrm{mg} / \mathrm{kg}$, via intramuscular administration and xylazine hydrochloride (CDB 09208), at a dose of $15 \mathrm{mg} / \mathrm{kg}$, via intramuscular administration. After anesthesia, the chicks were sacrificed by cervical dislocation.

A fragment of the middle section of the cervical trachea from each animal have been collected and divided into two samples. One sample was processed using a light microscope, while the other using an electron microscope.

The material collected was prepared for ultrastructural evaluations using the electronic transmission microscope and for microstructural evaluations using a light microscope, at the Histology Laboratory and at the Center of Electronic Microscopy at the Institute of Biomedical Science of the Federal University of Uberlândia (ICBIM-UFU).

In order to perform the analysis using an optical microscope, the samples of the trachea were fixed in a formalin solution of $10 \%$, and were processed according to the standard paraffin embedding protocol. The cuts were of a $6 \mu \mathrm{m}$ thickness, with two cuts performed on each analyzed trachea. The slides were stained using the standard technique for hematoxylin-eosin (HE).

The slides were observed with an optical microscope with a lens of $4 \mathrm{x}$, 10x and 40x. it has been 10 evaluation fields, in a way that all the tracheal mucosa on each slide could be observed for evaluating and defining the score. The images taken from the slides were digitalized on a Leica DM500 microscope, coupled to a Leica ICC50 camera, connected to computer with software for capturing and analyzing Leica LAS EZ images. 
The evaluations of the lesions tracheal lesions were performed following the score model used by Fauziah, Purton and Solomon (1996) (Table 1).

Table 1 - Scores for evaluating the degree of the lesions on the tracheal epithelium, using the light microscope method.

\begin{tabular}{cl}
\hline Scores & Description \\
\hline 0 & No lesion \\
1 & Small and isolated areas of cilia loss \\
2 & Ciliary agglutination and/or large areas of cilia loss \\
3 & Areas of local flaking \\
4 & Large areas of flaking \\
\hline
\end{tabular}

Source: Adapted from Fauziah, Purton and Solomon (1996).

The samples, fixed in glutaraldehyde at $3 \%$ concentration in a phosphate buffer at $0.1 \mathrm{M}$ and $\mathrm{pH}$ 7.2, were taken to the Electron Microscopy Center at ICBIM-UFU. The samples were cut into cubes of approximately $1 \mathrm{~mm}^{3}$ and placed in phosphate buffer at $0.1 \mathrm{M}$ and $\mathrm{pH} 7.2$ and bathed three times at five minutes each. Next, these were placed in a $1 \%$ solution of osmium tetroxide. After one hour, this solution received a dose of potassium ferrocyanide (1.25\%) and the material remained in this solution for another 30 minutes. At the end of 30 minutes, the fragments received a bath with a phosphate buffer at $0.1 \mathrm{M}$ and $\mathrm{pH} 7.2$ for five minutes and were dehydrated in an increasing alcohol content at 50\%, 70\%, 85\%, $90 \%, 95 \%, 100 \%, 100 \%$ and $100 \%$, where they remained five minutes in each concentration. Then, the fragments went through two baths of fifteen minutes of propylene oxide at $100 \%$, to remove the alcohol saturated in the samples. Later, the material was placed in a 2:1 EPON resin and propylene oxide solution for twelve hours. After that, the solution containing the material was placed in an oven at $37^{\circ} \mathrm{C}$ for four hours. Then, the resin and propylene oxide solution were substituted for a pure resin solution, in which the material remained for another four hours. Finally, the cubes were 
included in the EPON resin to be cut using an ultramicrotome to obtain ultrafine cuts (BOZZOLA and RUSSEL, 1998).

The ultrafine cuts were stained with uranyl acetate for 45 minutes, in oven at $37^{\circ} \mathrm{C}$ and later with lead citrate for thirty minutes, at room temperature, a procedure also based on Bozzola and Russel (1998). The evaluation and photographic documentation of the ultrafine cuts were performed on an electron transmission microscope (Zeiss Electron Microscope EM 109, coupled to digital image capturing system the Olympus Megaview3), in which the degree of the lesions were evaluated according to Table 2.

Table 2. Scores used to evaluate the degree of lesions on the tracheal epithelium, using the electron microscope method.

\begin{tabular}{cl}
\hline Scores & Description \\
\hline 0 & No lesion \\
1 & Few cells with superficial membrane lesion \\
2 & Few cells with alterations of the cilia structure and discrete cytoplasm alterations \\
3 & Many cells with alterations to the cilia structure and discrete alterations to the cytoplasm \\
4 & Large number of cells with severe cytoplasmic alterations, with loss of cilia and epithelium \\
& in areas.
\end{tabular}

As the subject deals with subjective score evaluations, in the statistical analyses, the non-parametric Kruskall Wallis test and the Wilcoxon signed rank test were used (CONOVER, 1998). For all the variables a significance level ofa $\leq 0.1$ was considered.

\section{Results and discussion}

There was no observable significant difference in the optical and electron microscope evaluations between the control group (P3) and process with peracetic acid (P1) (Table 3). The tracheal ciliated epithelial cells were intact during the control process (figure 1) and the process with peracetic acid (Figures 2 and 3). There were also not observed any histopathological alterations on the submucosa slide itself for the evaluated material. 
Table3 - Median scores for the light microscopy and electron microscopy evaluations.

\begin{tabular}{lccc}
\hline Evaluation method & $\mathrm{P} 1$ & $\mathrm{P} 2$ & P3 \\
\hline Light/optical microscope & $1.5 \mathrm{ab}$ & $2.5 \mathrm{~b}$ & 1st \\
Electron microscope & $1 \mathrm{a}$ & $2.5 \mathrm{a}$ & 2nd \\
\hline
\end{tabular}

Distinct letters on the same line represent different statistics between groups $(\mathrm{p} \leq 0.1)$.

This result is in agreement with the study performed by Khater et al. (2013). In this study Khaterand his collaborators use peracetic acid at a concentration of $0.05 \%$ in the form of baths in egg laying birds for control of the parasite Argaspersicus. Their studies show that peracetic acid was efficient and did not cause respiratory irritation or lesions to the eyes or skin.

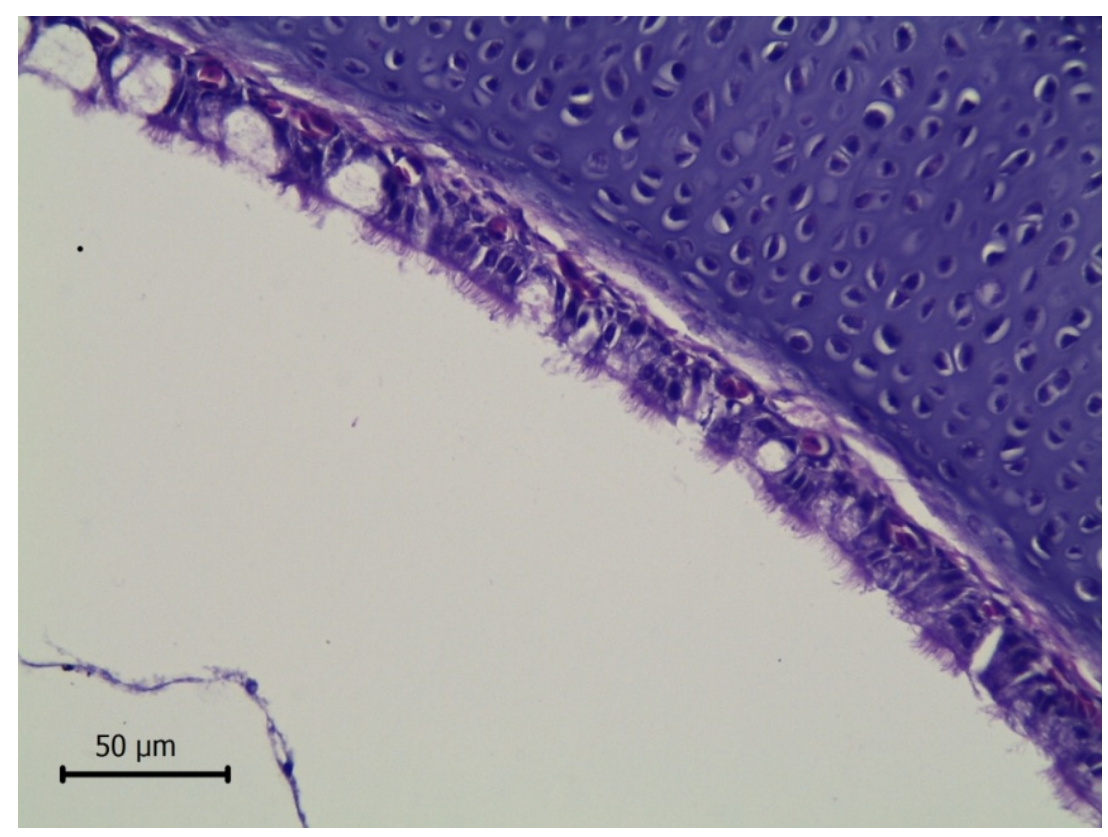

Figure 1. Histologic cut photomicrography of chick tracheal cilia in the control group, without exposure to disinfectants in the hatchery. Staining: Hematoxylin and Eosin. Light Microscope. Bar $=50 \mu \mathrm{m}$. 


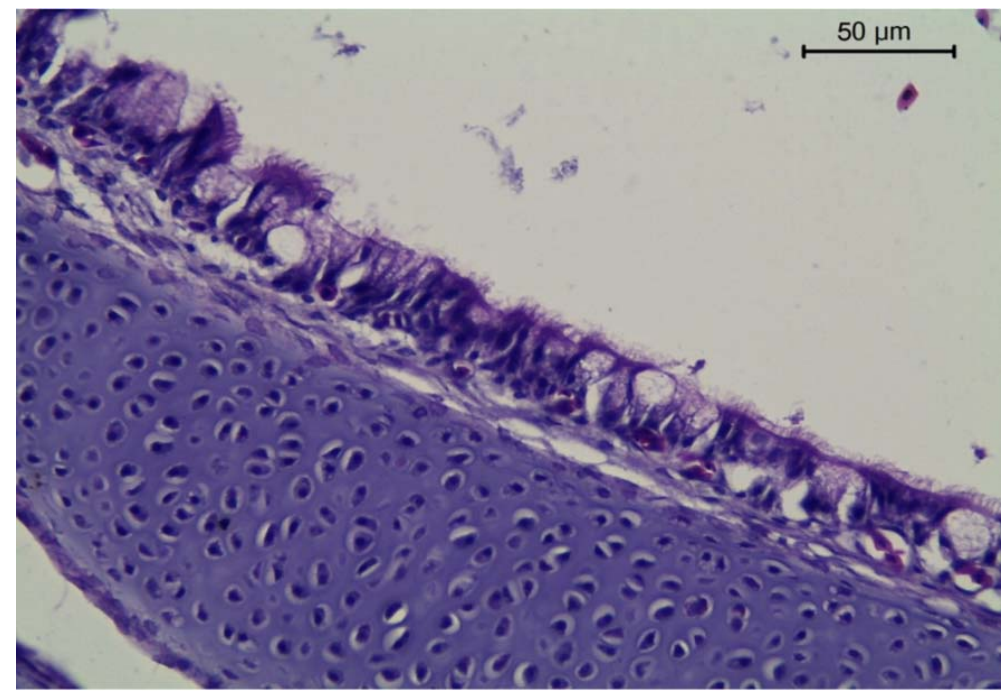

Figure2. Histologic cut photomicrography of the trachea wall of the chick exposed to micro-spraying with peracetic acid in the hatchery. Note that both the mucosa and all the ciliated epithelial have no lesions. Staining:Hematoxylin and Eosin. Light Microscope. Bar = $50 \mu \mathrm{m}$.

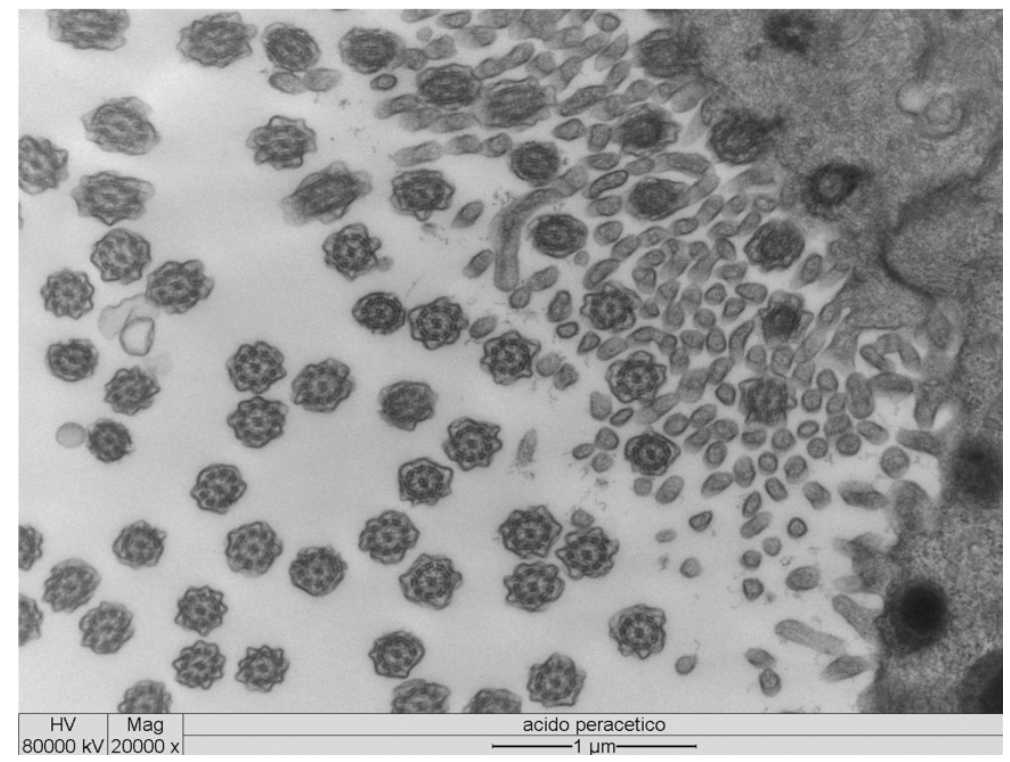

Figure 3. Eletromicrography of tracheal cilia in chicks exposed to micro-spraying with peracetic acid in the hatchery. Areas with cilia intact and epithelial preserved. Score 0. Bar $=1 \mu \mathrm{m}$.

Peracetic acid presents advantages in terms of application. The product remains active even in the presence of organic material, and is shown to be a product that after decomposing is non-toxic (acetic acid and oxygen) and non-mutagenic, has a low dependence on $\mathrm{pH}$ and needs only a 
short contact period in order to promote an effective disinfection. In addition, peracetic acid, in the absence of organic material, is more efficient than quaternary ammonia, sodium hypochlorite and active chlorine, against S. enteritidis. Peracetic acid is equally effective, independent of the organic material, against S. aureus and E. coli. Therefore, it is a valid option for disinfection in poultry production (JAENISCH, KUCHIISHI and COLDEBELLA, 2010).

Regarding the process using glutaraldehyde associated with quaternary ammonia, there was a significant optical microscope difference regarding the control group (P3). On the other hand, the chicks in process $\mathrm{P} 2$ presented severe lesions, such as areas with cilia loss and areas showing tracheal mucosal flaking. Whereas, Figures 4 and 5 show mucosa with flaking lesions and the absence of cilia (P2). According to the study performed by Zeiger, Gollapudi and Spencer (2005), similar to the effects reported in human beings, the main toxicological effects noted in animals exposed to glutaraldehyde are irritation when inhaled or in contact with the skin.

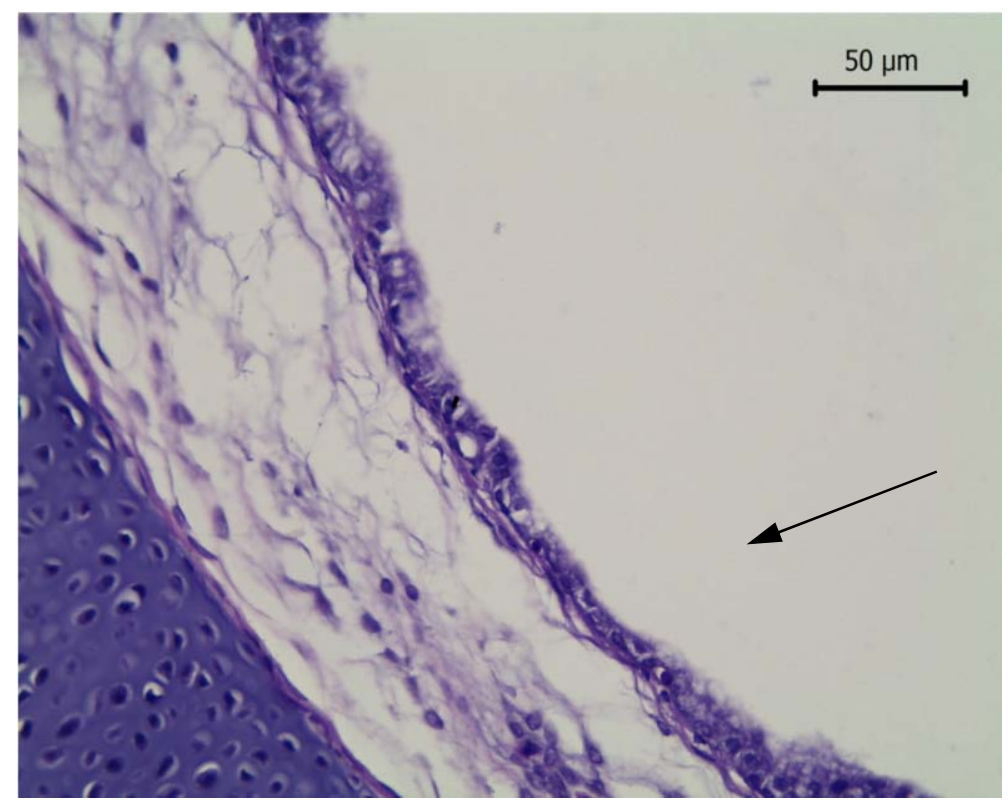

Figure 4. Histologic cut photomicrography of the tracheal cilia of chicks exposed to micro-spraying with glutaraldehyde associated with ammonia in the hatchery. Note that there are areas with an absence of cilia (arrows). Staining: Hematoxylin and Eosin. Light Microscope. Bar $=50 \mu \mathrm{m}$. 


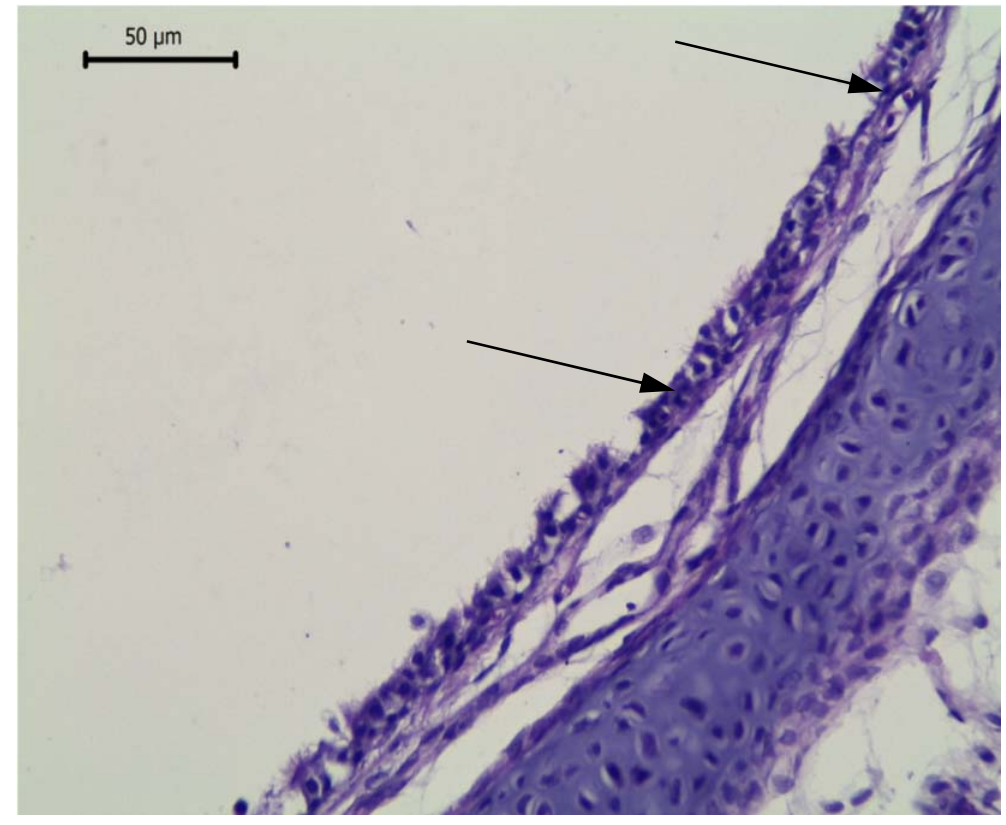

Figure 5. Histologic cut photomicrography of the tracheal cilia of chicks exposed to micro-spraying with glutaraldehyde combined with ammonia in the hatchery. Note that there are areas of flaking (arrows). Staining:Hematoxylin and Eosin. Light Microscope. Bar = $50 \mu \mathrm{m}$.

The disinfectant used in P2 is a combination of glutaraldehyde (42.5\%) and ammonia (7.5\%). Various disinfectants based on glutaraldehyde are formulated with quaternary ammonia composites to improve its detergent capacity. Nevertheless, glutaraldehyde is considered not to be efficient in hatcheries as it is very sensitive to $\mathrm{pH}$ variations. For example, a small variation in $\mathrm{pH}$ can result in an increase of up to five hours for glutaraldehyde to destroy a microorganism such as E. coli (MORGULIS and SPINOSA, 2005). In addition, according to Scott and Swetnam (1993), glutaraldehyde presents the highest cost when compared to other disinfectants commonly used in hatcheries for the processing of 10,000 disinfected eggs.

The lesions from chicks exposed to the environment with glutaraldehyde and ammonia (P2) were evaluated through electron microscope and did not show any significant difference in relation to the control group (P3). Another important aspect that needs to be taken into 
consideration, when using disinfectants, is the corrosive degradation of the equipment, due to its use with chemical agents. A number of products, although efficient in the microbiological aspect, present a high corrosive action, thus making them unsuitable for use. According to Ceretta et al., (2008) peracetic acid in concentrations of up to $2500 \mathrm{ppm}$ can be safely used on materials with stainless steel, copper and platinum. Besides these materials peracetic acid is used on other hatchery surfaces, such as pieces in aluminum, rubber and plastic, where its corrosive effect should be better understood.

Glutaraldehyde has a less corrosive effect than peracetic acid and the former can be used with items made of rubber, plastic, metal as well as with delicate cutting instruments (SPINOSA, GÓRNIAK and BERNARDI, 2006).

\section{Conclusion}

When using the doses set out in this study, peracetic acid can be used for disinfecting hatcheries to decrease contamination present during production processes. Thus, it causes less damage to the tracheal mucosa of chicks.

\section{References}

BOZZOLA, J. J.; RUSSEL, L. D. Electron microscopy: principles and techniquesfor biologists. 2. ed. Sudbury: Jones and Bartlett Publishers, 1998.

BRASIL. Resolução RDC nº 91, de 28 de novembro de 2008. Proíbe o uso isolado de produtos que contenham paraformaldeído ou formaldeído, para desinfecção e esterilização, regulamenta o uso de produtos que contenham tais substâncias em equipamentos de esterilização e dá outras providências. Agência Nacional da Vigilância Sanitária. Diário Oficial da República Federativa do Brasil, Brasília, 01 
de dezembro de 2008. Disponível em: <http://bvsms.saude.gov.br/bvs/saudelegis/ anvisa/2008/res0091_28_11_2008.html>. Acessoem: 16 jan. 2018.

CERETTA R, A.; PAUlA, M. M. S.; ANGIOlETTO, Ev.; MEIER, M. M.; MITELLSTADT, F. G.; PICH, C. T.; JUNIOR, S. A.; ANGIOLETTO, E. Evaluation of the effectiveness of peracetic acid in the sterilization of dental equipment. Indian Journal of Medical Microbiology, v. 26, n. 2, p. 117-122, 2008.

CONOVER, W. J. Pratical nonparametric statistics. 3. ed. New York: Ed. John Wiley, 1998. $584 \mathrm{p}$.

AL-MASHHADANI, E. H.; BECK, M. M. Effect of Atmospheric Ammonia on the Surface Ultrastructure of the Lung and Trachea of Broiler Chicks. Poultry Science, v. 64, p.2056-2061, 1985.

FAUZIAH, O.; PURTON, M. D.; SOLOMON, S. E. Scanning electron microscopy of the respiratory epithelium of chicks fumigated with formaldehyde vapour. British Poultry Science, v. 37, p. 563-570, 1996.

FREITAS, A. G.; GUSTIN, P. C.; NEVES, A. C. R. S.; ROCHA, J. V.; MENDES, A. C. J.; SILVA, P. L.; BELETTI, M. E. Microscopia do epitélio das vias respiratórias de pintos de um dia Gallusgallus submetidos a vapor de formaldeído no nascedouro. Veterinária Notícias, Uberlândia, v. 12, n. 2, p. 110, Set 2006.

GONZALES, E.; CAFÉ, M. B. Produção de pintinhos com qualidade total. In: MACARI, M.; GONZÁLES, E. Manejo da incubação. Jaboticabal: FACTA, 2003. cap. 5 , p. 515-526.

HAYRETDAG, S.; KOLANKAYA, D. Investigation of the Effects of Pre-Incubation Formaldehyde Fumigation on the Tracheal Epithelium of Chicken Embryos and Chicks. Turkish Journal of Veterinary Animal Sciences, v. 4, p. 263-267, 2008. 
JAENISCH, F. R. F.; KUCHIISHI, S. S.; COLDEBELLA, A. Atividade antibacteriana de desinfetantes para uso na produção orgânica de aves. Ciência Rural, v. 40, n. 2, p. 384-388, 2010.

KHATER, H. F.; SEDDIEK, S. A.; EL-SHORBAGY, M. M.; ALI, A. M. The acaricidal efficacy of peracetic acid and deltamethrin against the fowl tick, Argaspersicus, infesting laying hens. ParasitologyResearch, v. 112, n. 1, p. 259269, 2013.

MORGULIS, M. S. F. A.; SPINOSA, H. S. Antimicrobianos: Desinfetantes. In: PALERMO NETO J., SPINOSA, H. S.; GÓRNIAK, S. L. Farmacologia Aplicada a Avicultura: Boas Práticas no manejo de Medicamentos. São Paulo: Editora Rocca Ltda, 2005, p. 105-113.

SCOTT, T. A.; SWENAM, C. Screening sanitizing agents and methods of application for hatching eggs II. Effectiveness against microorganisms on the egg shell. The Journal Applied Poultry Research, v. 2, n. 1, p. 7-11, 1993.

SPINOSA, H. S.; GÓRNIAK, S. L.; BERNARDI, M. Farmacologia Aplicada a Medicina Veterinária. 4. ed. Rio de Janeiro: Guanabara Koogan, 2006. 288 p.

ZEIGER, E.; GOLLAPUDI, B.; SPENCER, P. Genetictoxicityandcarcinogenicitystudiesofglutaraldehyde-a review. Mutation Research, v. 589, n. 2, p. 136-151, 2005. 